\title{
PERANCANGAN SISTEM INVENTORI, PENJUALAN DAN OTOMATISASI SURAT JALAN PT BAJA INDO PERKASA
}

\author{
Reza Fahlavi \\ Program Studi Teknik Informatika, Fakultas Teknik dan Ilmu Komputer, \\ Universitas Indraprasta PGRI \\ Jalan Raya Tengah No 80, Kelurahan Gedong, Pasar Rebo, Jakarta Timur \\ rezafahlavi73@gmail.com
}

\begin{abstract}
Abstrak
Sistem inventori dan penjualan adalah sistem yang bertanggung jawab terhadap pendataan dan penjualan suatu barang, sistem seperti ini adalah hal krusial bagi semua perusahaan oleh sebab itu sistem harus dibuat seefektif dan seefisien mungkin. Tujuan penelitian ini adalah membangun dan menyediakan sistem inventori, penjualan dan mengotomatiskan pembuatan surat jalan pada PT Baja Indo Perkasa. Metode penelitian yang digunakan adalah metode penelitian kualitatif untuk dapat mendapatkan data sesuai yang terjadi di lapangan. Penelitian membuahkan hasil dengan terciptanya sistem inventori dan penjualan yang bermanfaat bagi perusahaan, manfaat tersebut antara lain memudahkan pencatatan inventori dan menghemat banyak waktu dalam penjualan dan pencetakan surat jalan. Simpulan dari penelitian ini adalah dengan diterapkannya sistem inventori, penjualan dan otomatisasi surat jalan membuat operasional perusahaan lebih efektif.
\end{abstract}

Kata Kunci: Perancangan sistem, Inventori, Penjualan.

\begin{abstract}
Sales and inventory systems are systems that are responsible for the data collection and sale of goods, a system like this is crucial for all companies, therefore the system must be made as effective and efficient as possible. The purpose of this study is to build and provide an inventory system, sales and automate the production of travel documents at PT Baja Indo Perkasa. The research method used is a qualitative research method to be able to get data according to what happens in the field. The research produced results by creating a sales and inventory system that was beneficial to the company. These benefits included facilitating the recording of inventories and saving a lot of time in the sale and printing of travel documents. The conclusion of this research is that the implementation of inventory, sales and automation systems makes the company's operations more effective.
\end{abstract}

Keywords: System design, Inventory, Sales.

\section{PENDAHULUAN}

Perkembangan zaman yang semakin moderen saat ini ditandai dengan pesatnya perkembangan teknologi yang begitu cepat, hampir semua lapisan masyarakat telah mengenal dan merasakan manfaat teknologi baik untuk memenuhi kebutuhan mereka akan informasi maupun menunjang produktifitas mereka dalam pekerjaan. Perkembangan teknologi komputer diikuti pula dengan meningkatnya jumlah pengguna komputer di dunia (Putri, 2016), tidak terkecuali mereka yang menggunakannya untuk bekerja, dengan berkembangnya teknologi membuat produktifitas para pekerja menjadi lebih besar, hal ini kemudian ditangkap oleh para pelaku bisnis untuk dapat memanfaatkan kemajuan teknologi untuk dapat meningkatkan produktifitas para pekerja mereka yaitu salah satunya dengan mengkomputerisasi sistem yang ada dalam model bisnis mereka yang menjadikan produktifitas pekerjanya meningkat.

Kemajuan teknologi yang pesat ini kemudian membuat setiap pelaku bisnis melirik komputerisasi bagi sistem bisnis yang mereka jalankan untuk dapat meningkatkan produktifitas pekerja dan meningkatkan keuntungan yang mereka dapat nantinya, tidak terkecuali pada PT Baja Indo Perkasa yang berlokasi di Jl.Peternakan III No 10 Cengkareng Jakarta Barat. PT Baja Indo Perkasa berupaya meningkatkan produktifitas karyawan mereka dengan berencana melakukan komputerisasi pada sistem pengelolaan stok barang dan penjualan yang mereka jalankan sampai saat ini. 
Sistem pengelolaan barang dan penjualan saat ini yang masih menggunakan cara konvensional yaitu pencatatan setiap stok dan penjualan dengan metode kertas sebenarnya sudah cukub baik pada PT Baja Indo Perkasa namun hal ini akan merepotkan apabila sudah berurusan dengan dokumentasi stok beberapa tahun kebelakang, lembar laporan hilang dan rusak seolah pasti terjadi. Dari kasus tersebutlah PT Baja Indo Perkasa ingin melakukan komputerisasi dan memodernisasi sistem mereka.

Tujuan penelitian ini adalah untuk merancang sistem inventori, penjualan dan otomatisasi surat jalan pada PT Baja Indo Perkasa aplikasi yang mampu mencatat setiap stok barang, bahan yang dimiliki, mencetak laporan stok, penjualan bila dibutuhkan dan setiap penjualan yang mereka lakukan hingga mampu mengotomatisasi pembuatan surat jalan untuk dapat meningkatkan efisiensi dan menghilangkat terbuangnya waktu dari setiap pembuatan laporan stok, penjualan, dan membuat secara manual surat jalan yang memerlukan cukup banyak waktu.

\section{PENELITIAN RELEVAN}

Penelitian oleh Muhammad Farhan dengan judul PERANCANGAN SISTEM INVENTORI DAN PENJUALAN PAKAIAN DI KONVEKSI AULIA COLLECTION, tujuan dari penelitian tersebut adalah membuat aplikasi yang dapat memudahkan perusahaan dalam mengelola data produk yang ada, memanfaatkan produk, dan membantu pengambilan keputusan terhadap kebutuhan produk yang ada. sistem inventori dan penjualan pada perusahaan, menjadikan lebih baik dan menjadi lebih terstruktur(Farhan, 2020).

Penelitian oleh Agung Cahyo Wijoyo dan Dian Hermanto2 dengan judul ANALISIS DAN PERANCANGAN SISTEM INFORMASI INVENTORY PADA PT. INSAN DATA PERMATA, , tujuan agar semua kegiatan yang berhubungan dengan pendaftaran pelanggan, pengolahan barang, pengolahan transaksi pengadaan barang, penjualan barang dan laporan tidak lagi secara manual. aplikasi yang dibuat ini dapat memudahkan pegawai di PT Insan Data Permata dalam mencatat dan mendataan barang dan transaksi penjualan barang. Pengolahan data PT Insan Data Permata lebih efektif, serta keamanan terhadap data lebih terjamin, Proses dalam pembuatan laporan dapat dilakukan dengan cepat dan akurat serta efisien, Memudahkan pegawai untuk memantau atau mengontrol data yang ada dalam database(Wijoyo \& Hermanto, 2020).

Kedua penelitian tersebut sangat relevan dengan penelitian yang sedang peneliti lakukan, keduanya memiliki tujuan untuk dapat membuat sistem dan mempermudah pekerjaan user dalam pendataan dan pembuatan laporan. Perbedaan dari penelitian tersebut adalah dalam penelitian kali ini peneliti tidak hanya memfokuskan pada inventori saja namun juga pada proses penjualan dan pembuatan surat jalan.

\section{METODE PENELITIAN}

Desaim penelitian yang digunakan pada penelitian ini adalah dengan metode penelitian kualitatif. Penelitian kualitatif adalah jenis penelitian yang temuan-temuannya tidak diperoleh melalui prosedur statistik atau bentuk hitungan lainnya dan bertujuan mengungkapkan gejala secara holistik-kontekstual melalui pengumpulan data dari latar alami dengan memanfaatkan diri peneliti sebagai instrumen kunci (Sugiarto, 2015). Dalam penelitian dan pengumpulan data tidak hanya mencari dan mengumpulkan data, tetapi langsung juga dengan melakukan kualifikasi dan pemilahan terhadap data tersebut, mengolah dan menganalisasi data, membangun hipotesis menjadi teori dan menyusunnya bagian demi bagian untuk dapat dijadikan sebuah laporan.

Langkah-langkah pokok yang digunakan pada metode ini yaitu menentukan masalah yang ingin di selidiki, mengumpulkan data atau informasi yang ada dilapangan, menganalisis dan menjelaskan masalah yang ditemukan serta membuat laporan hasil penelitaian).

Pengumpulan data pada penelitian kali ini salah satunya adalah dengan pendekatan wawancara, wawancara dilakukan langsung dengan karyawan dan berlokasi di PT Baja Indo Perkasa. Metode wawancara ini bertujuan mendapatkan data seakurat mungkin mengenai permasalahan yang dihadapi langsung oleh karyawan PT Baja Indo Perkasa. 


\section{HASIL DAN PEMBAHASAN}

\section{Analisa Permasalahan}

Berdasarkan analisa yang dilakukan, dapat diidentifikasi permasalahan pada sistem yang sedang berjalan adalah sebagai berikut :

1. Proses dalam pengolahan stok dan penjualan barang masih manual.

2. Pengolahan dokumentasi stok dan penjualan belum tersimpan secara rapih.

3. Pembuatan laporan dan surat jalan masih manual.

\section{Alternatif Penyelesaian Masalah}

Dari permasalahan yang ditemukan maka sebagai tindak lanjut penyelesaiannya adalah :

1. Merancang aplikasi sistem informasi pengolahan data yang dapat mempermudah mengelola stok barang, penjualan dan laporan pada PT Baja Indo Perkasa.

2. Merancang sebuah aplikasi yang menyiapkan surat jalan dari setiap penjualan pada PT Baja Indo Perkasa.

3. Membangun dan mengkomputerisasi sistem pada PT Baja Indo Perkasa sehingga meningkatkan efisiensi dan meningkatkan kinerja karyawan menjadi lebih baik.

\section{Aturan Bisnis Sistem Diusulkan}

Aturan bisnis sistem yang diusulkan pada PT Baja Indo Perkasa adalah sebagai berikut:

1. Login

Karyawan yang bertugas melakukan login pada aplikasi

2. Stok masuk dan keluar

Karyawan yang bertugas mengisi form stok barang keluar dan atau stok barang masuk, form laporan yang sudah diinput akan masuk dan tercatat pada database.

3. Laporan stok barang

Karyawan yang bertugas bisa mencetak laporan barang keluar dan atau masuk sesuai yang dibutuhkan

4. Penjualan dan pencetakan surat jalan

Karyawan yang bertugas mengisikan form penjualan dan sistem otomatis akan membuatkan surat jalan

\section{Use Case Diagram}

Berikut merupakan penggambaran tentang sistem yang diusulkan dalam bentuk use case diagram :

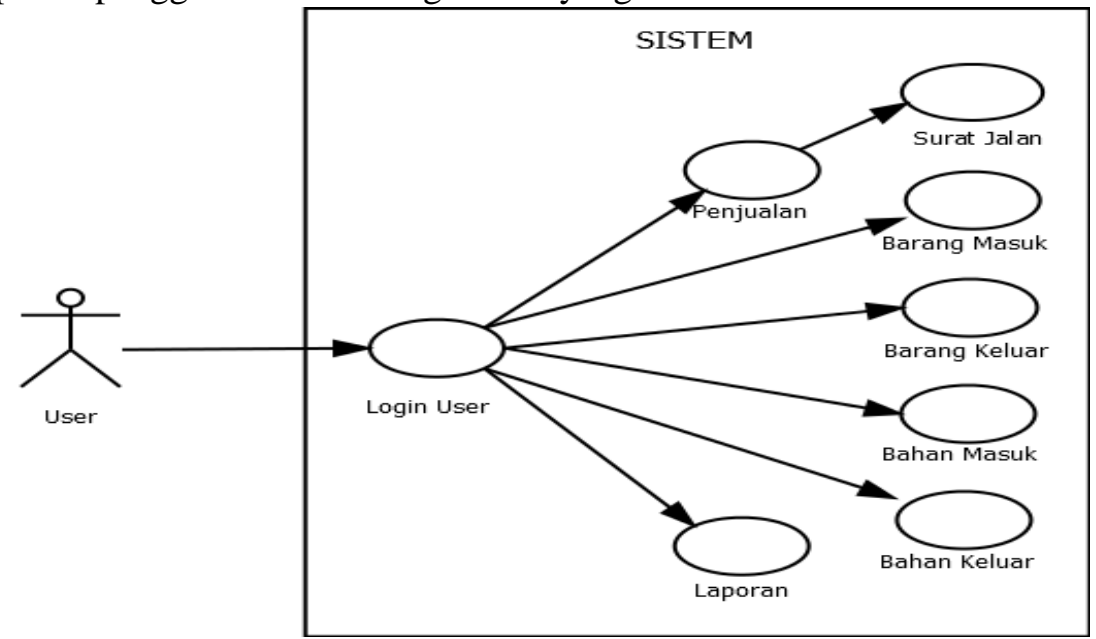

Gambar 1 : Use Case Diagram yang Diusulkan 


\section{Tampilan Aplikasi}

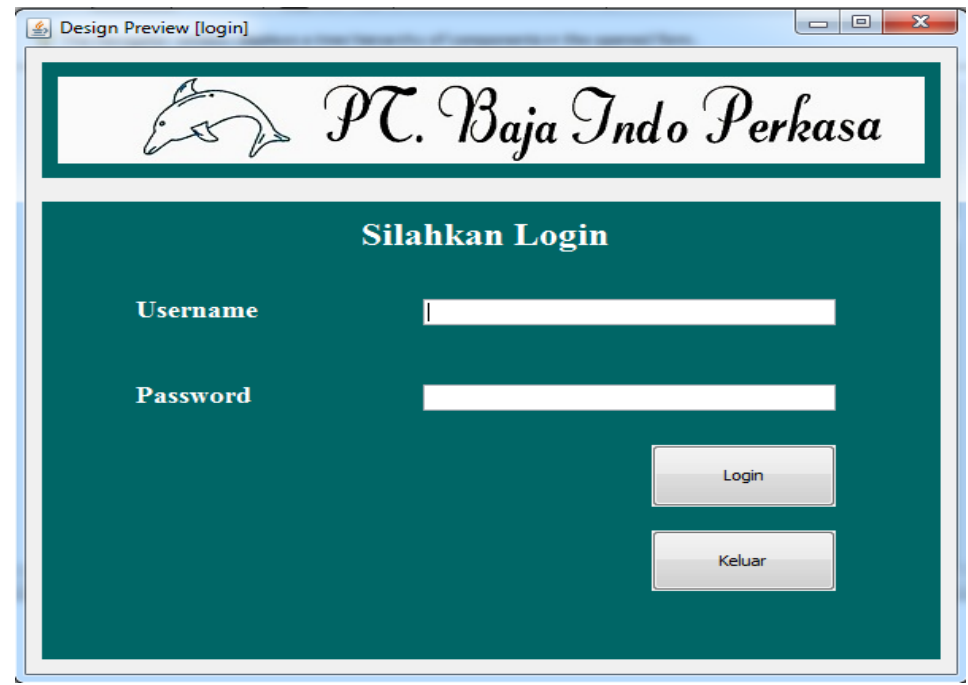

Gambar 2 : Tampilan form Login

Gambar diatas merupakan form login yang digunakan untuk bisa masuk ke dalam sistem.

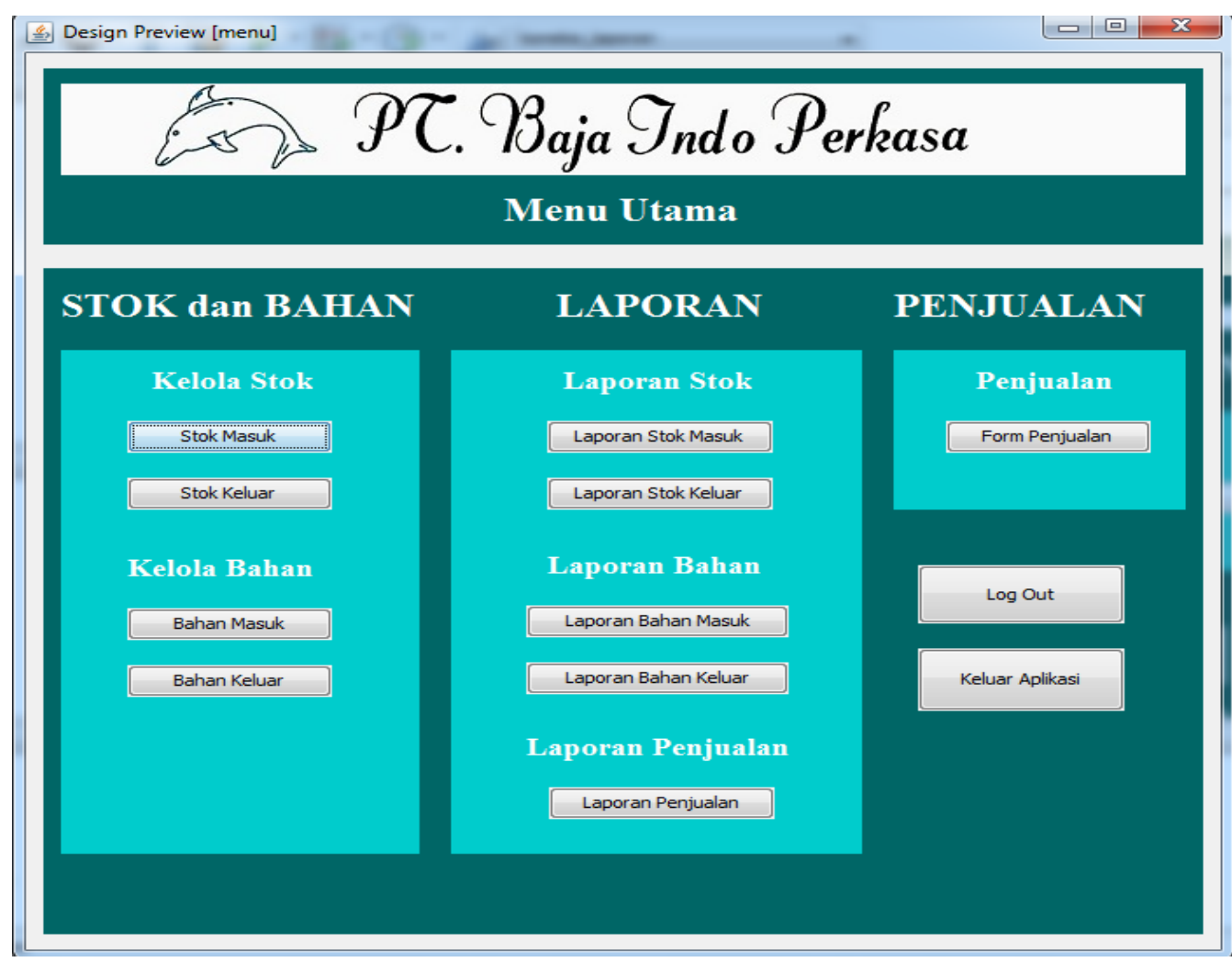

Gambar 3 : Tampilan Menu Utama

Gambar tersebut merupakan tampilan menu utama sistem yang dibuat. 
Jurnal Riset dan Aplikasi Mahasiswa Informatika (JRAMI)

Vol QZ No II Tahun ZQZI

e-ISSN : 2715-8756

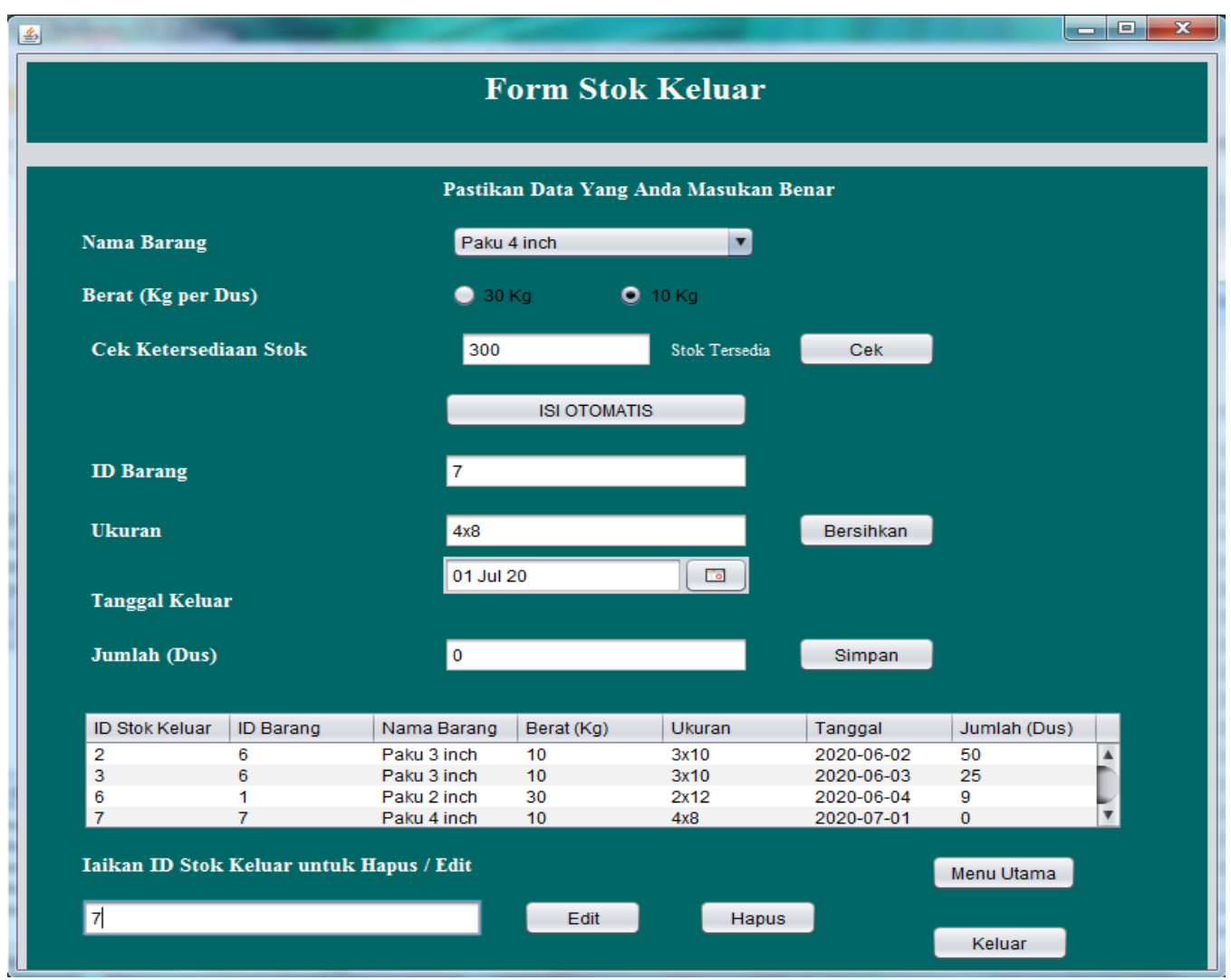

Gambar 4 : Tampilan form Kelola Stok

Gambar diatas merupakan form pengelolaan stok (stok keluar).

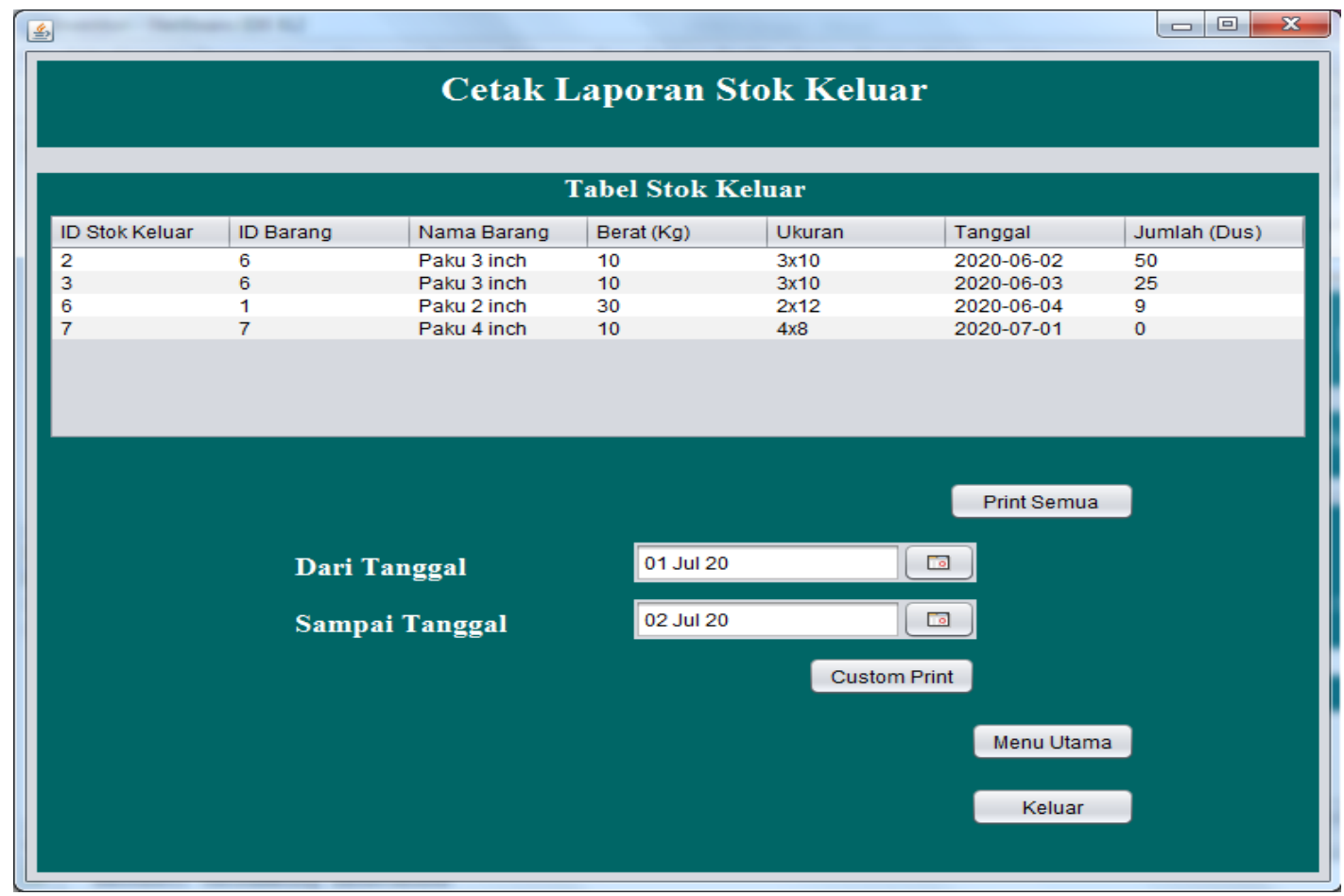

Gambar 5 : Tampilan form Cetak Laporan

Gambar diatas merupakan form pencetakan laporan (stok keluar). 
Jurnal Riset dan Aplikasi Mahasiswa Informatika (JRAMI)

Vol QZ No II Tahun ZQZI

e-ISSN : 2715-8756

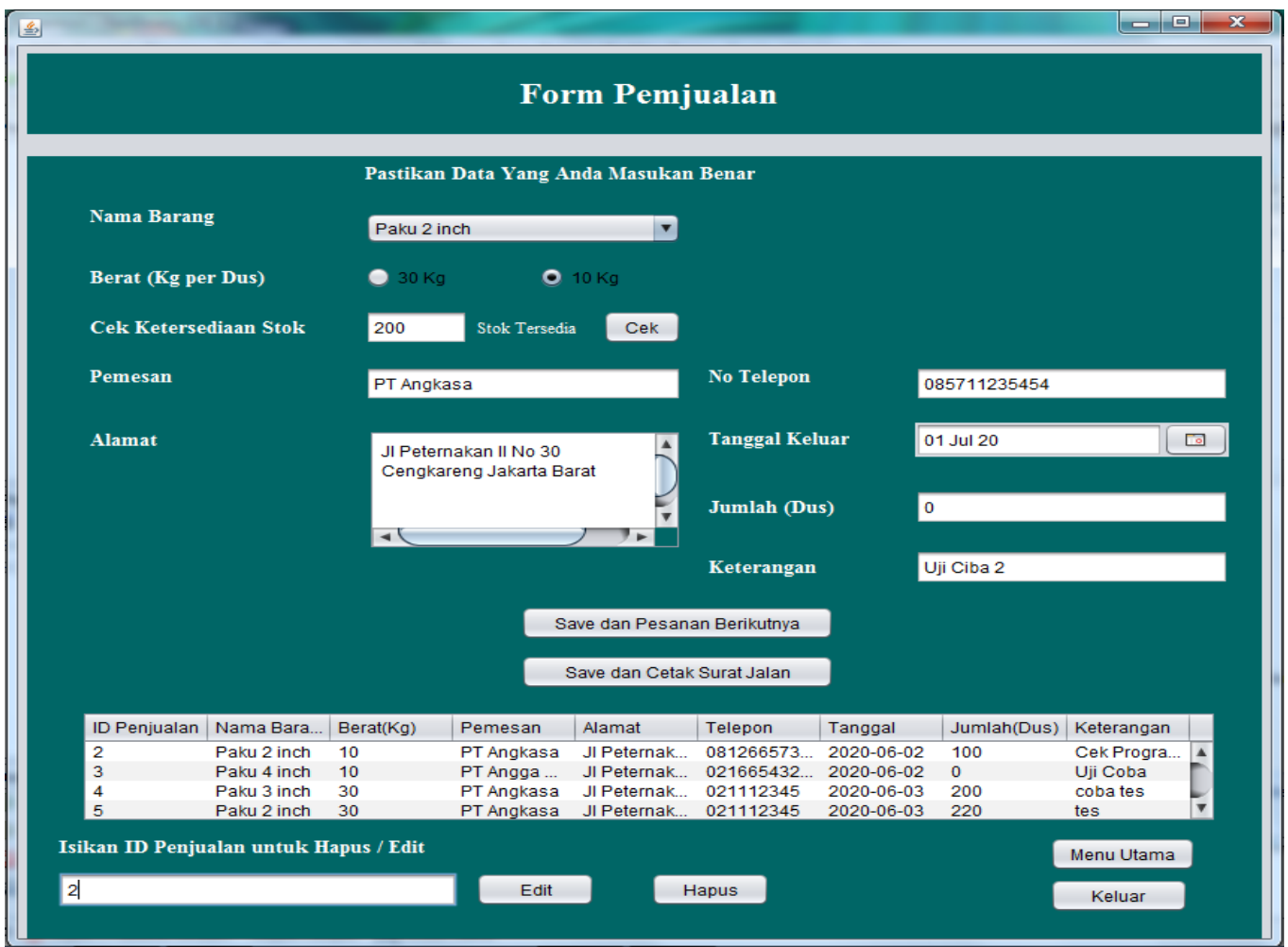

Gambar 6 : Tampilan form Penjualan

Gambar diatas merupakan form penjualan

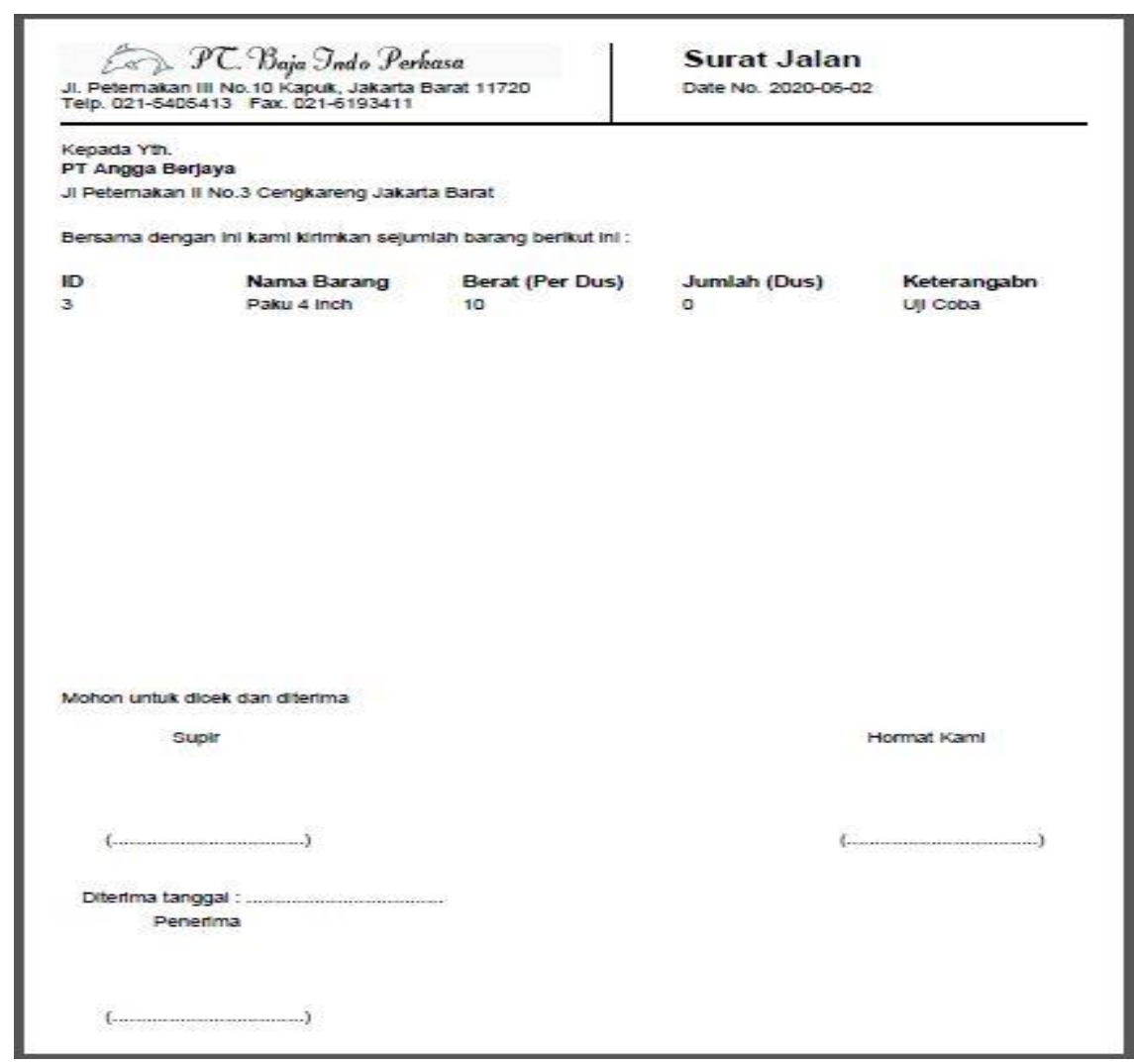

Gambar 7 : Tampilan Surat Jalan

Gambar diatas merupakan contoh surat jalan yang akan dicetak. 


\section{SIMPULAN}

Pada penelitian ini berhasil dibuat sebuah sistem inventori, penjualan dan otomatisasi surat jalan pada PT Baja Indo Perkasa. Sistem ini dapat memudahkan karyawan dalam mengolah data dan jika sewaktu-waktu diperlukan informasi dan data dari inventori dan penjualan tersebut dapat dengan cepat diperoleh, surat jalanpun akan otomatis dibuat saat ada penjualan hal ini akan sangat menghemat waktu dan meningkatkan produktifitas karyawan.

Dengan adanya sistem yang telah terkomputerisasi ini semua permasalahan dalam pembuatan laporan, pembuatan surat jalan serta pengolahan data inventori dan penjualan pada PT Baja Indo Perkasa Cengkareng bisa diatasi dan proses bisnis yang berjalan dapat lebih baik dan lebih efisien.

\section{DAFTAR PUSTAKA}

Andri, K. (2008). Perancangan Sistem Informasi dan Aplikasinya. Yogyakarta: Gava Media.

Anhar, S. T. (2010). Panduan Menguasai PHP \& MySQL Secara Otodidak. Jakarta: mediakita.

Farhan, M. (2020). Perancangan Sistem Inventory dan Penjualan Pakaian di Konveksi Aulia Collection. Jurnal Riset Dan Aplikasi Mahasiswa Informatika (JRAMI), 1(02), 171-176. https://doi.org/10.30998/jrami.v1i02.234

Gata, W., \& Gata, G. (2013). Sukses membangun aplikasi penjualan dengan java. Jakarta: Elex Media Komputindo.

Jogiyanto, H. M. (2005). Analisa dan Perancangan Sistem Informasi. Yogyakarta: Andi Offset.

Ladjamudin, A. B. B. (2005). Analisis dan desain sistem informasi. Yogyakarta: Graha Ilmu.

Mulyanto, A. (2009). Sistem Informasi Konsep dan Aplikasi. Pustaka Pelajar. Yogyakarta: Pustaka Pelajar.

Sugiarto, E. (2017). Menyusun Proposal Penelitian Kualitatif: Skripsi dan Tesis. Yogyakarta: Suaka Media Diandra Kreatif.

Sutarman, B. (2012). Pengantar Teknologi Informasi. Jakarta: Bumi Aksara.

Wijoyo, A. C., \& Hermanto, D. (2020). Analisis dan Perancangan Sistem Informasi Inventory pada PT Insan Data Permata. Jurnal Riset Dan Aplikasi Mahasiswa Informatika (JRAMI), 1(02), 165-170. https://doi.org/10.30998/jrami.v1i02.231 